\title{
Nitrogen Deposition in Different Mediterranean Forest Types along the Eastern Adriatic Coast
}

\author{
Lucija Lovreškov ${ }^{1}$, Ivan Limić ${ }^{*}$, Lukrecija Butorac ${ }^{2}$, Tamara Jakovljević ${ }^{1}$
}

(1) Croatian Forest Research Institute, Division for Forest Ecology, Cvjetno naselje 41, HR10450 Jastrebarsko, Croatia; (2) Institute for Adriatic Crops and Karst Reclamation, Put Duilova 11, HR-21000 Split, Croatia

*Correspondence: e-mail: ivan.limic@krs.hr
Citation: Lovreškov L, Limić I, Butorac L, Jakovljević T, 2021. Nitrogen Deposition in Different Mediterranean Forest Types along the Eastern Adriatic Coast. Southeast Eur for 12(2): 115-122. https://doi. org/10.15177/seefor.21-15.

Received: 29 Sep 2021; Revised: 30 Nov 2021; Accepted: 2 Dec 2021; Published online: 16 Dec 2021

\begin{abstract}
Mediterranean forests along the eastern Adriatic coast have an important ecological role. However, few studies have been conducted on nitrogen deposition so far. To improve this knowledge, the main aims of our study were: (i) to estimate nitrogen inputs and determine differences among the four Mediterranean forests, (ii) to determine the seasonal behaviour of $\mathrm{N}$ deposition compounds, and (iii) to discuss the results in relation to forest type and precipitation. Measurements were carried out over a two-year period on four plots in two regions: holm oak and pubescent oak in Istria, Aleppo pine and black pine in Dalmatia. Bulk open field and throughfall deposition were sampled with continuously exposed collectors. Measurements, analyses and data validation of precipitation and $\mathrm{N}$ compounds were carried out. The results showed that the highest average monthly precipitation was recorded in the black pine plot and the lowest in the Aleppo pine plot. Nitrate and ammonia in conifer plots in throughfall samples were lower than in bulk open field samples, indicating possible retention by the tree canopy. The results revealed a higher amount of $\mathrm{N}$ deposition collected in broadleaved forests than in conifer forests indicating the washing out of $\mathrm{N}$ compounds previously deposited and accumulated in forest canopy. The chemistry of $\mathrm{N}$ deposition was strongly influenced by local and anthropogenic sources as well as neighbouring countries. Our results may fill the knowledge gap in understanding the influence of precipitation and seasonality of $\mathrm{N}$ compounds in different Mediterranean forest types along the eastern Adriatic coast.
\end{abstract}

Keywords: precipitation; nitrogen deposition; nitrate; ammonium; Mediterranean forests; pubescent oak; holm oak; black pine; Aleppo pine

\section{INTRODUCTION}

The emission of air pollution in Europe has significantly increased in the course of the twentieth century. Large amounts of nitrogen oxides $\left(\mathrm{NO}_{x}\right)$ are released by human activities, mainly fossil fuel combustion in industry, power plants, heating systems and transport, while ammonia $\left(\mathrm{NH}_{3}\right)$ from agriculture and farming. This increase has affected $\mathrm{N}$ cycling in ecosystems worldwide (Erisman et al. 2013) and is considered one of the threats to Mediterranean sustainability, along with climate change and ozone (De Marco et al. 2019, Jakovljević et al. 2021).

Nitrogen, as well as other air pollutants, is carried by air masses and rain from regional and long-range transport to the rural areas (Perez et al. 2008, Pey et al. 2009, Aguillaume et al. 2017). Atmospheric deposition and its transformation in contact with vegetation are of great importance in understanding its effects on forests. It has an impact on forest ecosystems through eutrophication by nitrogen and soil acidification, thus altering soil properties and processes (Clark et al. 2007). Changes in the soil chemistry may lead to imbalances in nutrient supply and subsequently to unbalanced nutrition of the trees. Nutrient imbalance will affect canopy photosynthesis and in turn decrease forest vitality (Lu et al. 2008, de Vries et al. 2014). For example, critical loads for nutrient nitrogen and their exceedances were both important for defoliation (De Marco et al. 2014).

It is known that cycling and deposition of $\mathrm{N}$ in Mediterranean-type ecosystems are highly seasonal processes conditioned by the Mediterranean climate 
(Ochoa-Hueso et al. 2011). For airborne total nitrate $\left(\mathrm{NO}_{3}{ }^{-}\right)$ and ammonium $\left(\mathrm{NH}_{4}^{+}\right)$, the spatial coverage is slightly better in the western Mediterranean than in eastern regions (Ochoa-Hueso et al. 2011). However, the potential ecological effects of $\mathrm{N}$ deposition in Mediterranean-type climates have been less investigated (Balestrini et al. 2007, Bobbink et al. 2010, De Marco et al. 2014, Ferretti et al. 2014, Aguillaume 2015, García-Gómez et al. 2018, Jakovljević et al. 2019) even though they are usually recognized as hotspots of biodiversity (Myers et al. 2000).

Mediterranean forest ecosystems along the eastern Adriatic coast are of very high significance because of ecological and social value and they are invaluable to the human and ecological functions they provide (Matic et al. 2011, Topić and Butorac 2011, HAZU 2013, Topić et al. 2020). These ecosystems are very sensitive and degraded due to numerous wildfires causing the reduction of the vegetative cover and enlarged flow of tourists during the summer season and the constant increase in human activity (Topić and Butorac 2011, Topić et al. 2020).

Nitrogen compounds in Mediterranean forests are transferred from other rural parts of Croatia or from neighbouring countries (Skevin-Sovic et al. 2012, HAOP 2015). The highest exceedances of $\mathrm{NH}_{3}$ ceilings (25\%) in Mediterranean part of Croatia was found in 2017 (EEA 2019) while the exceedance of $\mathrm{NO}_{x}$ was not recorded in 2017 and 2018 (AZO 2018, AZO 2019).

Considering the described peculiarity and fragility of the Mediterranean environment, there is an increasing need to improve the knowledge of Mediterranean forest ecosystems (Jakovljević et al. 2019).

The aims of our research were (i) to estimate nitrogen inputs and identified differences between the forests, (ii) to determine the seasonal behaviour of $\mathrm{N}$ deposition compounds, and (iii) to discuss the results in relation to forest type and precipitation.

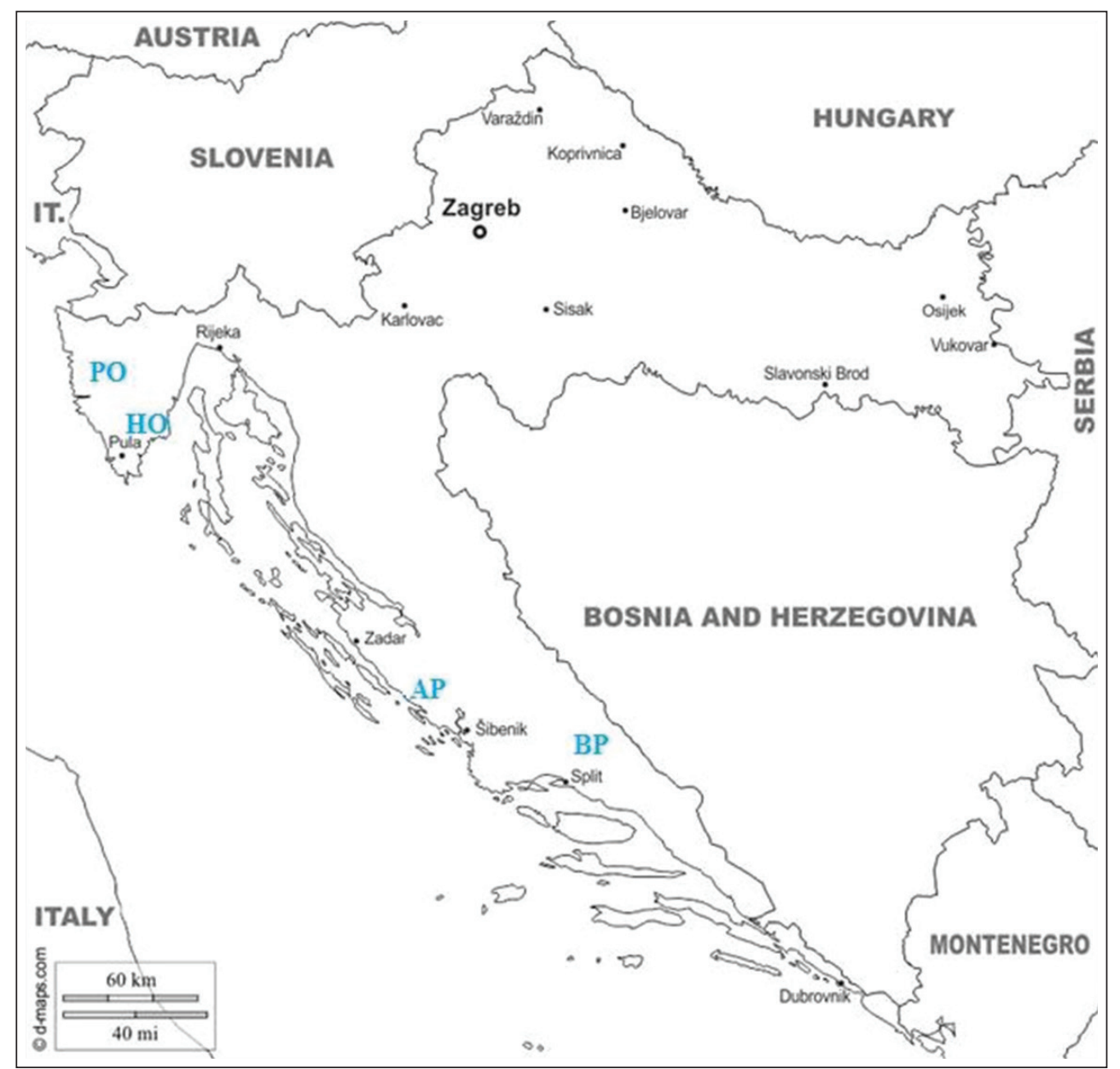

Figure 1. Location of the study area: pubescent oak (PO) and holm oak (HO) plots in Istria and Aleppo pine (AP) and black pine (BP) plots in Dalmatia. 


\section{MATERIALS AND METHODS}

\section{Study Area}

The measurements were performed in different Mediterranean forest ecosystems along the eastern Adriatic coast (Figure 1) on the most dominant deciduous broadleaves species: pubescent oak (Quercus pubescens Wild.) and evergreen holm oak (Quercus ilex L.), and conifer species: black pine (Pinus nigra J.F. Arnold.) and Aleppo pine (Pinus halepensis Mill.).

According to the Köppen climate classification, the plots are distributed in the hot-summer Mediterranean climate subtype (Csa) (Köpen et al. 2011). Average annual precipitation ranges from $879 \mathrm{~mm}$ (AP-Vrana plot) to 1277 $\mathrm{mm}$ (BP-Split plot), while the mean air temperature varying from $12.4^{\circ} \mathrm{C}$ (BP-Split plot) to $13.4^{\circ} \mathrm{C}$ (PO-Poreč plot). Description of the sampling plots are shown in Table 1.

\section{Sampling and Analysis}

Sampling, measurements and analyses on the plots were all carried out according to the ICP Forests (International Co-operative Programme on Assessment and Monitoring of Air Pollution Effects on Forests) manuals (Clarke et al. 2016, König et al. 2016). The study period for N deposition was from January 2017 to December 2018. Deposition was sampled using continuously exposed, randomly placed collectors, comprising a 1-L graduated polyethylene bottle with a funnel with a $14 \mathrm{~cm}$ diameter. Nine collectors were placed beneath the forest canopy to collect throughfall deposition (THR) samples (Figure 2a, b). Bulk open field deposition (BOF) was sampled using three collectors, continuously exposed (Figure 2c, d). Samples were collected biweekly for the whole period from January 2017 to December 2018. The analyses of ion concentrations were performed on filtered samples $(0.45 \mu \mathrm{m})$. Samples of atmospheric deposition were collected biweekly (Clarke et al. 2016, König et al. 2016). Ion chromatography was used to determine concentrations of two $\mathrm{N}$ compounds $\left(\mathrm{NO}_{3}^{-}, \mathrm{NH}_{4}^{+}\right)$ (ISO 10304, ISO 14911).

After samples were collected and analysed, some samples were excluded due to contamination or precipitation less than $2 \mathrm{~mm}$. These data were not included in the statistical analysis, but the precipitation volume of the excluded samples was included in calculating monthly/annual precipitation (Izquieta-Rojano et al. 2016). Some technical problems led to missing data during the study period, especially related to precipitation measurements. These problems included theft, vandalism and instrument failure due to extreme storms.

Statistical analyses were performed using programs Microsoft Office Excel 2010 and Statsoft Statistica 13. Data in the tables are expressed as the mean \pm standard deviation $( \pm S D)$. The annual mean concentrations of the measured $N$ compounds were calculated as volume-weighted means. The monthly deposition fluxes were obtained following the same procedure. The Wilcoxon signed test was used to test whether BOF and THR depositions of $\mathrm{N}$ ions were significantly different. A significant difference was considered at the level of $p<0.05$. Data normality was tested using the KolmogorovSmirnov test, where the data was considered normally distributed if the $D$ value was insignificant at $p<0.05$.

\section{RESULTS AND DISCUSSION}

The measurements were conducted on four different Mediterranean forest ecosystems to identify the amount and differences in seasonal precipitation and $\mathrm{N}$ deposition.

Total precipitation in the studied period at all plots was generally lower in THR, ranging between $1047 \mathrm{~mm}$ in Aleppo pine (AP) to $2193 \mathrm{~mm}$ in black pine (BP) (Table 2). The amount of rain collected in BOF for all four plots ranged between $1272 \mathrm{~mm}$ in AP to $2578 \mathrm{~mm}$ in BP. Average monthly precipitation differed markedly between the studied sites. The highest average monthly precipitation was determined at BP plot $(123 \mathrm{~mm})$ and the lowest at AP plot $(85 \mathrm{~mm})$ (Table 2).

However, exceptionally in summer on AP plot in July 2018, the value of THR was higher than BOF, 135 and 95 $\mathrm{mm}$, respectively (Figure $3 \mathrm{e}, \mathrm{f}$ ). Several factors can influence the difference in rain volume between BOF and THR, such as maximum precipitation rate, vapour pressure deficit or wind speed (Mużyło et al. 2012, Aguillaume et al. 2017). In our case, the smaller amount of precipitation in BOF could be due to water evaporation from the collector due to high temperatures and wind drying during the summer months.

Furthermore, difference between precipitation in the BOF and THR samples indicated that the water quantity

Table 1. Description of sampling plots in two regions along the Adriatic coast.

\begin{tabular}{|c|c|c|c|c|}
\hline Code & PO & HO & AP & BP \\
\hline Forest type & Pubescent oak & Holm oak & Aleppo pine & Black pine \\
\hline Region & Istria & Istria & Dalmatia & Dalmatia \\
\hline Latitude, N & $45^{\circ} 14^{\prime} 59^{\prime \prime}$ & $44^{\circ} 51^{\prime} 41^{\prime \prime}$ & $43^{\circ} 53^{\prime} 23^{\prime \prime}$ & $43^{\circ} 41^{\prime} 59^{\prime \prime}$ \\
\hline Longitude, E & $13^{\circ} 43^{\prime} 53^{\prime \prime}$ & $13^{\circ} 59^{\prime} 24^{\prime \prime}$ & $15^{\circ} 33^{\prime} 47^{\prime \prime}$ & $16^{\circ} 26^{\prime} 34^{\prime \prime}$ \\
\hline Elevation (m) & 264 & 3 & 20 & 550 \\
\hline Distance to the sea $(\mathrm{km})$ & 9.78 & 0.50 & 2.90 & 17.19 \\
\hline Nearest town & Poreč & Pula & Zadar/Šibenik & Split \\
\hline Distance to the nearest town $(\mathrm{km})$ & 19 & 10 & $38 / 36$ & 24 \\
\hline
\end{tabular}




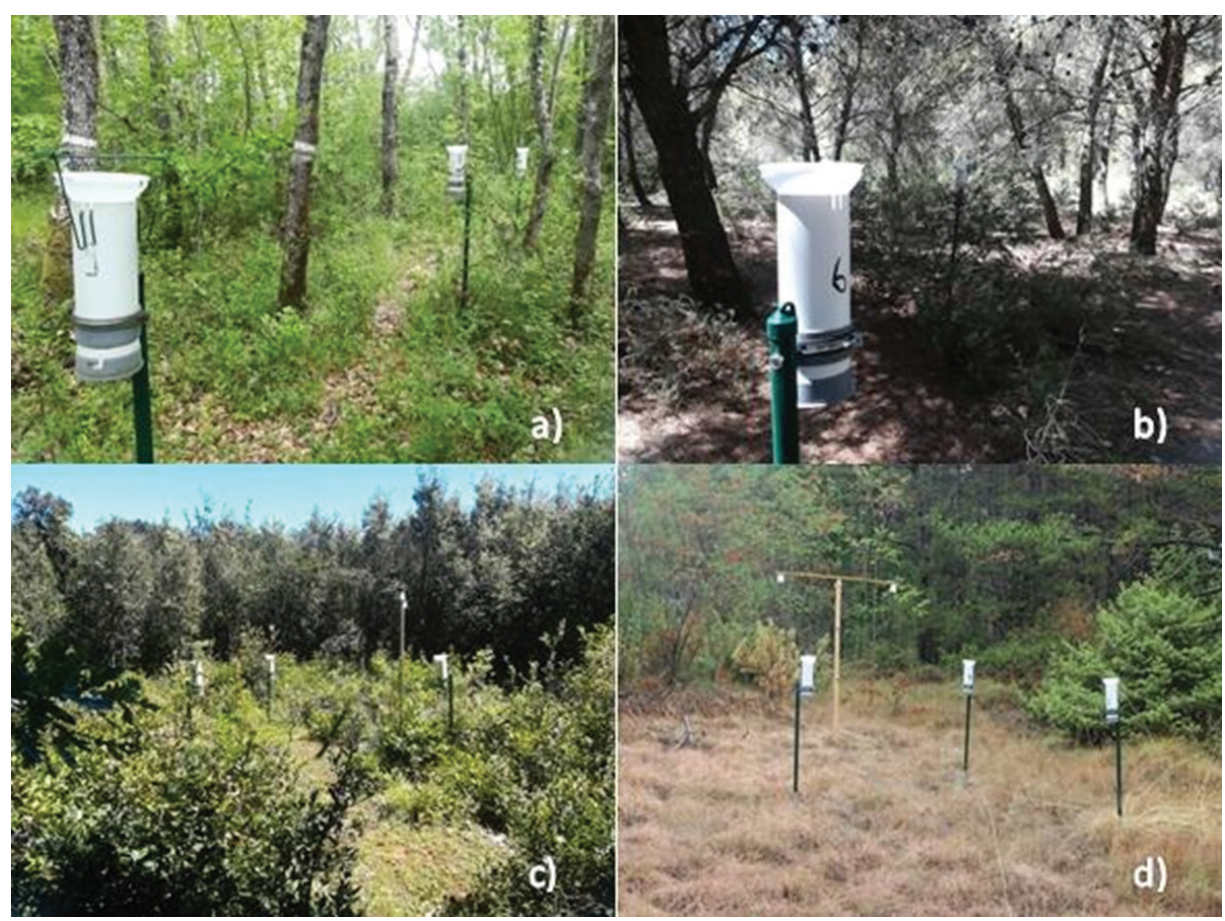

Figure 2. Collectors for throughfall deposition (THR) in (a) pubescent oak (PO) and (b) Aleppo pine (AP) and bulk deposition (BOF) in (c) holm oak (HO) and (d) black pine (BP).

was intercepted by the canopies (Aguillaume et al. 2017, Avila et al. 2017). The interception of rainwater by the canopy depends on the dominant forest type of the plot. In pubescent oak (PO) plot interception was $8 \%$, in holm oak (HO) plot it was $12 \%$ and in pine plots interception was $15 \%$ in BP and $18 \%$ in AP plot, respectively (Table 2). Similar interception values were found on deciduous plots in Italy where values ranged from $10 \%$ to $15 \%$, and for coniferous species ranged from $23 \%$ to $24 \%$ (Balestrini et al. 2007). On the other hand, in Spanish holm oak forests higher interception values up to $34 \%$ were found (Aguillaume 2015).

Average monthly $\mathrm{N}$ deposition differed between broadleaved and conifer plots (Table 2). In broadleaves plots, the $\mathrm{N}$ deposition of both compounds $\left(\mathrm{N}-\mathrm{NH}_{4}{ }^{+}\right.$and $\mathrm{N}-\mathrm{NO}_{3}{ }^{-}$) was higher in THR than in BOF.

Ammonium and $\mathrm{N}^{-\mathrm{NO}_{3}}$ - depositions were higher in $\mathrm{HO}$ than in PO plot, $8.22 \mathrm{meq} \mathrm{m}^{-2}$ and 6.27 meq $\mathrm{m}^{-2}$, and 3.81 meq $\mathrm{m}^{-2}$ and $3.21 \mathrm{meq} \mathrm{m}^{-2}$ respectively. The same was found

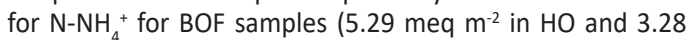
meq $\mathrm{m}^{-2}$ in $\left.\mathrm{PO}\right)$. Regarding $\mathrm{N}^{-\mathrm{NO}_{3}}$ - values they were slightly lower in $\mathrm{HO}$ plot (2.04 meq $\mathrm{m}^{-2}$ ) than in $\mathrm{PO}$ plot (2.41 meq $\mathrm{m}^{-2}$ ) (Table 2). On the contrary, on plots with conifer species lower $\mathrm{N}_{-} \mathrm{NH}_{4}^{+}$and $\mathrm{N}-\mathrm{NO}_{3}{ }_{3}^{-}$were found in $\mathrm{THR}$ than in BOF (Table 2). Deposition of $\mathrm{N}-\mathrm{NH}_{4}^{+}$in THR and BOF were higher in BP plot than in AP plot (3.51 meq $\mathrm{m}^{-2}$ and $1.43 \mathrm{meq} \mathrm{m}^{-2}$,

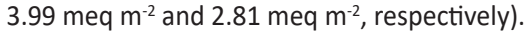

The same pattern for deposition of $\mathrm{N}^{-N_{3}-}$ in $\mathrm{THR}$ and BOF samples between BP and AP plot was found. In
THR samples, $\mathrm{N}-\mathrm{NO}_{3}$ - deposition on BP plot was 2.43 meq $\mathrm{m}^{-2}$ and on AP plot $1.65 \mathrm{meq}^{-2}$, and in BOF samples on AP and BP plot 1.96 and 3.05 meq $\mathrm{m}^{-2}$, respectively (Table 2). Considering $\mathrm{N}^{-\mathrm{NO}_{3}}$ - deposition in $\mathrm{AP}$ plot, it originates from wet air masses coming from the Adriatic Sea, and the fact that most of this land area is suitable for agricultural production also contributes to its concentration. Regarding $\mathrm{N}-\mathrm{NH}_{4}^{+}$, highest $\mathrm{N}-\mathrm{NH}_{4}^{+}$concentrations were measured on the $\mathrm{HO}$ and $\mathrm{PO}$ plots (in THR). These plots are also influenced by the intense agricultural activities in its surroundings, and this is highlighted by the high amount of ammonium (Jakovljević et al. 2019).

Considering throughfall $\mathrm{N}$ deposition, it reflects both wash-off of the dry deposited particles on tree canopies and the exchange with the leaf surfaces (absorption and leaching) (Balestrini et al. 2007, Jakovljević et al. 2013, Ferretti et al. 2014, Avila et al. 2017). Usually, it is expected to be higher as it was evident in the oak plots. However, $\mathrm{N}-\mathrm{NO}_{3}$ and $\mathrm{N}^{-} \mathrm{NH}_{4}^{+}$in THR samples were lower than in BOF samples on conifer plots (Table 2), indicating possible retention from the canopy (Jakovljević et al. 2019). Forest canopies can intercept the deposited $\mathrm{N}$ before it reaches the forest floor. In general, the effectiveness of particle uptake by trees is increased if their leaf and bark surfaces are rough or sticky (Becket et al. 1998). Using the canopy $\mathrm{N}$ budget method, Gaige et al. (2007) found that the canopy of the mature conifer forest retained more than $70 \%$ of $\mathrm{N}$ deposition. Uptake efficiencies by the canopy in the conifer forest was very high, around $90 \%$ for $\mathrm{N}-\mathrm{NH}_{4}{ }^{+}$and $70-80 \%$ for 
Table 2. Total amount of precipitation (V), average monthly precipitation (AV), interception between BOF and THR, average monthly deposition of $\mathrm{N}$ compounds $\left(\mathrm{N}-\mathrm{NO}_{3}, \mathrm{~N}-\mathrm{NH}_{4}{ }^{+}\right)$in bulk open field (BOF) and throughfall (THR) at the experimental plots during the study period (2017 and 2018).

\begin{tabular}{|c|c|c|c|c|c|c|c|}
\hline Plot & Sample type & Study period & $\underset{(\mathrm{mm})}{\mathbf{V}}$ & $\begin{array}{c}\text { AV } \\
(\mathrm{mm})\end{array}$ & $\begin{array}{l}\text { Interception } \\
(\%)\end{array}$ & $\begin{array}{c}\mathbf{N}-\mathrm{NH}_{4}^{+} \\
\left(\text {meq m}^{-2}\right)\end{array}$ & $\begin{array}{c}\mathrm{N}-\mathrm{NO}_{3}^{-} \\
\left(\mathrm{meq} \mathrm{m}^{-2}\right)\end{array}$ \\
\hline \multirow{2}{*}{ Pubescent oak (PO) } & BOF & 2017-2018 & 2013 & 88 & \multirow{2}{*}{8} & $3.28 \pm 3.95$ & $2.41 \pm 2.14$ \\
\hline & THR & 2017-2018 & 1863 & 81 & & $6.27 \pm 5.83$ & $3.21 \pm 2.24$ \\
\hline \multirow[b]{2}{*}{ Holm oak (HO) } & BOF & $2017-2018$ & 1969 & 94 & \multirow[b]{2}{*}{12} & $5.29 \pm 11.6$ & $2.04 \pm 1.98$ \\
\hline & THR & $2017-2018$ & 1742 & 83 & & $8.22 \pm 6.01$ & $3.81 \pm 3.31$ \\
\hline \multirow{2}{*}{ Aleppo pine (AP) } & BOF & 2017-2018 & 1272 & 85 & \multirow{2}{*}{18} & $2.81 \pm 2.40$ & $1.96 \pm 1.83$ \\
\hline & THR & $2017-2018$ & 1047 & 70 & & $1.43 \pm 1.07$ & $1.65 \pm 1.30$ \\
\hline \multirow{2}{*}{ Black pine (BP) } & BOF & $2017-2018$ & 2578 & 123 & \multirow{2}{*}{15} & $3.99 \pm 8.36$ & $3.05 \pm 3.19$ \\
\hline & THR & $2017-2018$ & 2193 & 104 & & $3.51 \pm 6.84$ & $2.43 \pm 2.73$ \\
\hline
\end{tabular}

$\mathrm{N}-\mathrm{NO}_{3}$, resulting in smaller THR deposition compared to the wet deposition (Sievering et al. 2007).

The Wilcoxon signed test showed that there was a significant level of differences between the average monthly precipitation in BOF and THR samples on the $\mathrm{HO}$ and $\mathrm{AP}$ plots (Table 3 ). There are number of reasons affecting the difference between precipitation, such as extreme weather (e.g., rainstorms, hailstorms, etc.) and human activities (e.g., forest management and forest planting) (Cisneros et al. 2018). Processes of rainfall interception of forest canopy depend on the various properties of the rainfall characteristics; especially the rainfall amount and intensity and drop properties such as the number of drops, their velocity, diameter, and median volume diameter. The vegetation periods and leaf area index values can also influence the spatial variability of THR (Zabret et al. 2018, Zabret and Šraj 2018).

In PO and BP plots there were no significant differences between average monthly precipitation of BOF and THR (Table 3).

Although it was expected that a vegetation period would significantly affect the precipitation amount between BOF and THR in the deciduous forest, this was not the case on our PO plot. Our results in PO plot showed slight differences in rainfall amount between leafed and leafless periods (Figure 3). Similar observations were found by Mużyło et al. (2012).

Furthermore, significant differences between BOF and THR deposition of $\mathrm{N}$ compounds can be observed at oak plots. In AP plot significant difference for $\mathrm{N}$ compounds was not found, while in the BP plot statistical analyses revealed a significant difference in deposition between BOF and THR for $\mathrm{N}_{-} \mathrm{NO}_{3}$ - (Table 3).

The precipitation volume and monthly deposition of N compounds in BOF and THR in 2017 and 2018 on four selected plots are presented in Figure 3.

In all studied plots precipitation mainly occurred in autumn and winter. The trend could be seen on all plots except on AP plots (Figure 3e, f). This plot also had the smallest amount of precipitation.

It was expected that in the summer months the precipitation would be the lowest, or there would be no precipitation at all that could be observed on PO, AP and BP plots in 2017 (Figure 3a, b, e, f, g, h). These results are not uncommon for the Mediterranean climate that is characterised by seasonal incidence of precipitation (FAO and Plan Bleu 2018). A similar trend was observed in western Mediterranean (Izquieta-Rojano et al. 2016). Moreover, the precipitation amount was identified as an important meteorological factor affecting the amount and annual distribution of $\mathrm{N}$ deposition. Changes in the $\mathrm{N}$ behaviour of ecosystems are driven by fluctuations of physical drivers (i.e., weather conditions) and biological factors (Shibata et al. 2015).

The results obtained indicated a higher amount of $\mathrm{N}$ deposition collected in broadleaved forests than in conifer forests (Figure 3 ). This fact suggested that the $\mathrm{N}$ compounds previously deposited and accumulated in the forest canopy

Table 3. Significant level of the differences between average monthly precipitation bulk and throughfall fluxes according to the Wilcoxon signed test (marked as bold as significant for $\mathrm{p}<0.05$ ).

\begin{tabular}{llll}
\multicolumn{1}{c}{ Plot (BOF-THR) } & V & N-N ${ }_{4}^{+}$ & N-NO $_{3}^{-}$ \\
\hline Pubescent oak (PO) & 0.4654 & $\mathbf{0 . 0 0 4 3}$ & $\mathbf{0 . 0 1 5 2}$ \\
Holm oak (HO) & $\mathbf{0 . 0 0 2 1}$ & $\mathbf{0 . 0 0 1 9}$ & $\mathbf{0 . 0 0 0 4}$ \\
Aleppo pine (AP) & $\mathbf{0 . 0 2 7 7}$ & 0.0546 & 0.3967 \\
Black pine (BP) & 0.0766 & 0.6051 & $\mathbf{0 . 0 2 7 6}$ \\
\hline
\end{tabular}



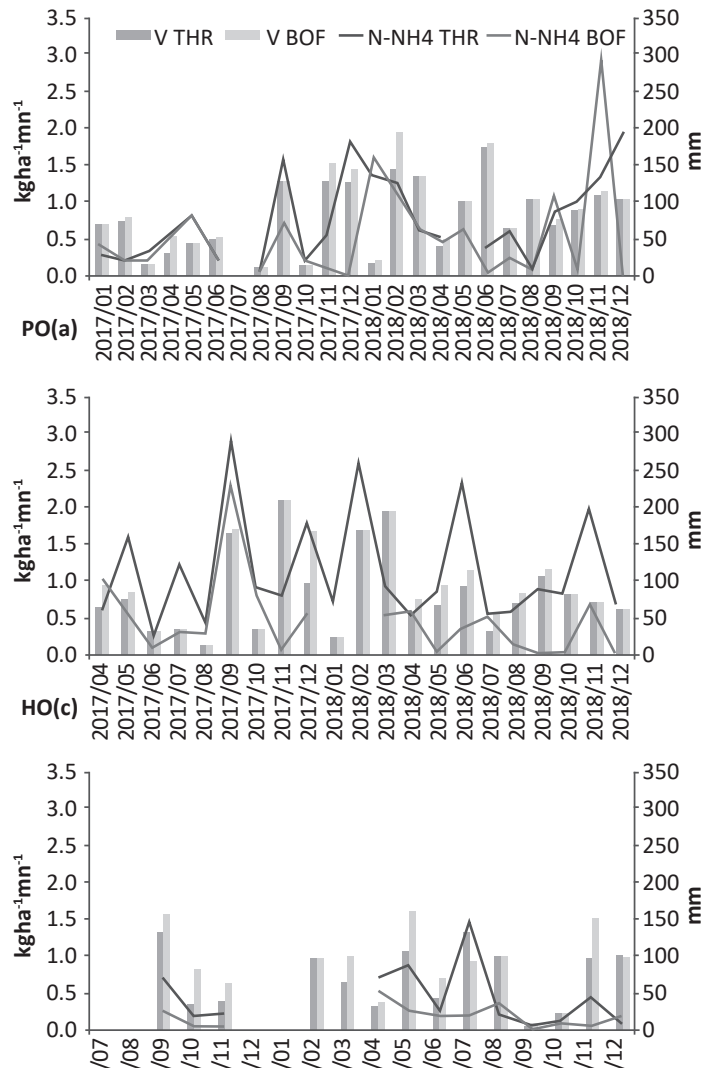

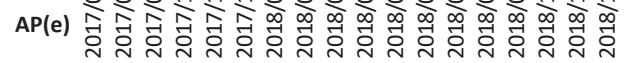

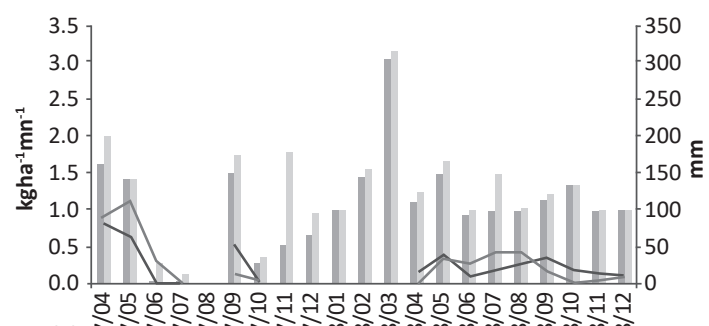

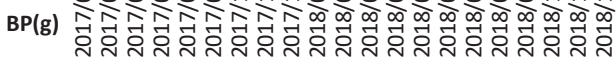
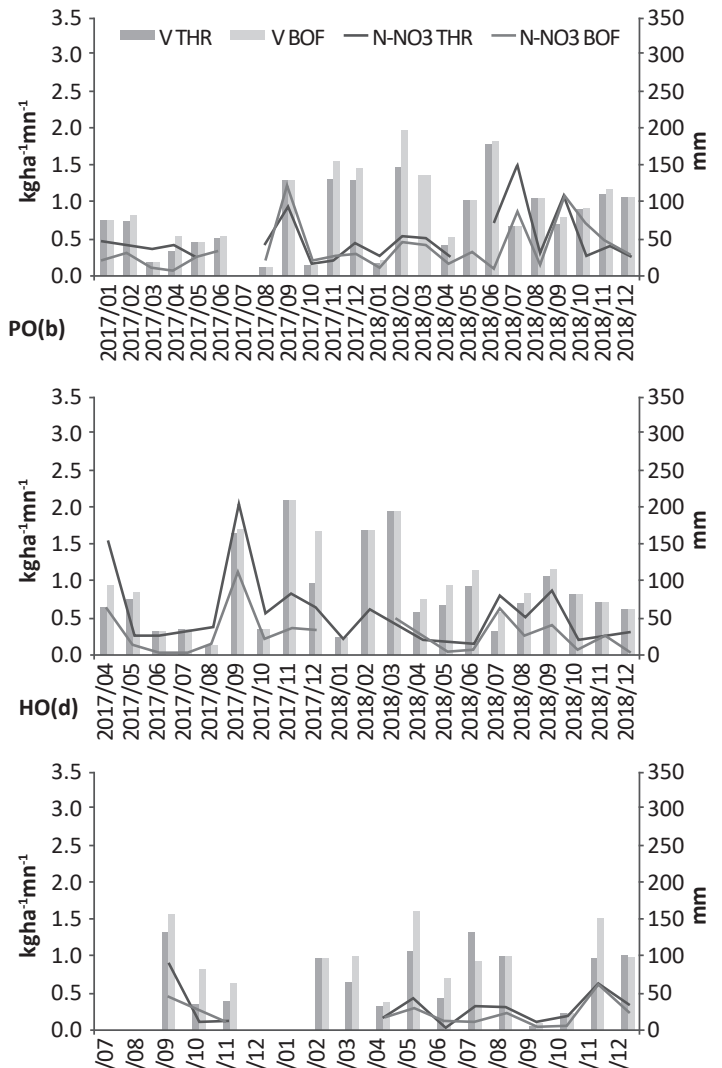

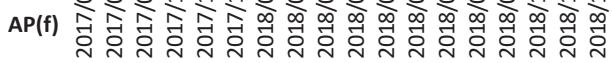

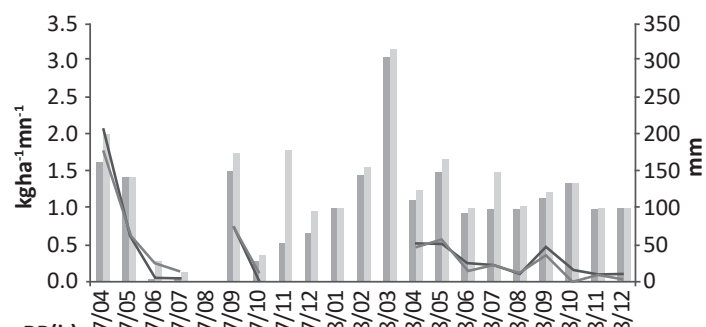

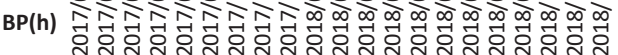

Figure 3. Monthly bulk (BOF) and throughfall (THR) deposition of nitrogenous compounds ( $\mathrm{kg} \mathrm{N} \mathrm{ha}^{-1} \mathrm{mn}^{-1}$ ) and precipitation volume $(\mathrm{mm})$ at the four monitoring plots: PO-pubescent oak (a, b), HO-holm oak (c, d), AP-Aleppo pine (e, f) and BP-black pine (g, h).

were washed out in subsequent rain events. Although rainfall amount may affect these peaks, it is likely that other factors were involved, since variations in the size of the peaks are not proportional to the precipitation amount.

In the Mediterranean area, $\mathrm{N}$ deposition accumulates on plant surfaces during dry periods, becoming available as high $\mathrm{N}$ concentration in pulses with rainfall events (Meixner and Fenn 2004, Ochoa-Hueso et al. 2011, Aguillaume et al. 2016). These pulses could be observed in THR on all plots. They could be explained by a major contribution from drydeposited particles, washed out after the driest period of the year. It was more evident on $\mathrm{PO}$ and $\mathrm{HO}$ plots where the collected deposition during August 2017 was washed out in September 2017 (Figure 3a-d).

The highest monthly deposition of $\mathrm{N}$ compounds can be observed in THR and BOF throughout the year for PO and $\mathrm{HO}$ plots located in Istria (Figure 3a-d) unlike BP and AP plots in Dalmatia (Figure 3e-g). Istria is a region located on the border with Slovenia and Italy. It was expected that the plots on the Istrian peninsula ( $\mathrm{PO}$ and $\mathrm{HO}$ ) would have higher $\mathrm{N}$ depositions influenced also by urbanistically and industrially developed neighbouring countries. 


\section{CONCLUSION}

The atmospheric inputs of nitrogen compounds in different Mediterranean forest types along the eastern Adriatic coast were estimated. The results showed that throughfall $\mathrm{N}$ deposition was higher in oak forests rather than pine forests, indicating possible wash-off from the oak canopies and possible retention from pine canopies. High $\mathrm{N}$ concentration amounts in THR samples were present during the summer period as a result of major contribution from dry-deposited particles washed out after the driest period of the year. Our results revealed in pubescent oak forest that slight differences in rainfall amount between leafed and leafless periods were present. Depending on the study site, different anthropogenic activities and possible influence of neighbouring countries were identified as potential sources of $\mathrm{N}$ deposition. Further research is desirable to monitor the potential effects of $\mathrm{N}$ deposition on the forests of eastern Adriatic coast.

\section{Author Contributions}

TJ and LB conceived and designed the research, LB and IL carried out the field measurements, LL and IL processed the data and performed statistical analysis; project administration TJ and LL, TJ funding acquisition, TJ and LL performed laboratory measurements, TJ secured the research funding, TJ, LB supervised the research, $\mathrm{LL}$ and $\mathrm{IL}$ wrote the manuscript, TJ and LB helped to draft the manuscript.

\section{Funding}

This research has been fully supported by the Croatian Science Foundation under the project IP-2016-06-3337 "Assessment of Atmospheric Deposition and Ozone levels in Mediterranean Forest ecosystems (DepOMedFor)". The work of PhD students Lucija Lovreškov and Ivan Limić have been fully supported by the "Young researchers' career development project - training of doctoral students" of the Croatian Science Foundation funded by the European Union from the European Social Fund.

\section{Acknowledgments}

We are grateful to all operators who have performed sampling in the fields, particularly Dragan Jakšić, Monika Hlebić and Renata Tubikanec from the Croatian Forest Research Institute for their activity in the laboratory.

\section{Conflicts of Interest:}

The authors declare no conflict of interest.

\section{REFERENCES}

Aguillaume L, 2015. Nitrogen deposition at Mediterranean holm oak forests: loads and indicators. PhD Thesis, Universitat Autònoma de Barcelona, Spain, $196 \mathrm{p}$.

Aguillaume L, Izquieta-Rojano S, García-Gómez H, Elustondo D, Santamaría JM, Alonso R, Avila A, 2017. Dry deposition and canopy uptake in Mediterranean holm-oak forests estimated with a canopy budget model: A focus on N estimations. Atmos Environ 152: 191200. https://doi.org/10.1016/j.atmosenv.2016.12.038.

Aguillaume, L, Rodrigo A, Avila A, 2016. Long-term effects of changing atmospheric pollution on throughfall, bulk deposition and streamwaters in a Mediterranean forest. Sci Total Environ 544: 919928. https://doi.org/10.1016/i.scitotenv.2015.12.017.

Avila A, Aguillaume L, Izquieta-Rojano S, García-Gómez H, Elustondo D, Santamaría JM, Alonso R, 2017. Quantitative study on nitrogen deposition and canopy retention in Mediterranean evergreen forests. Environ Sci Pollut $R$ 24(34): 26213-26226. https://doi. org/10.1007/s11356-017-8861-4.

AZO, 2018. Izvješće o praćenju kvalitete zraka na području Republike Hrvatske za 2017. godinu. Available online: $\mathrm{http}: / /$ www.haop.hr/hr/ novosti/izvjesce-o-pracenju-kvalitete-zraka-na-podrucju-republikehrvatske-za-2017-godinu (16 September 2021). [in Croatian].

AZO, 2019. Izvješće o praćenju kvalitete zraka na području Republike Hrvatske za 2018. godinu. Available online: http://www.haop.hr/hr/ godisnja-izvjesca-o-pracenju-kvalitete-zraka-na-podrucju-republikehrvatske/godisnja-izvjesca-o (16 September 2021). [in Croatian].

Balestrini R, Arisci S, Brizzio MC, Mosello R, Rogora M, Tagliaferri A, 2007. Dry deposition of particles and canopy exchange: Comparison of wet, bulk and throughfall deposition at five forest sites in Italy. Atmos Environ 41(4): 745-756. https://doi.org/10.1016/j. atmosenv.2006.09.002.

Beckett KP, Freer-Smith, PH, Taylor G, 1998. Urban woodlands: their role in reducing the effects of particulate pollution. Environ Pollut 99(3): 347-360. https://doi.org/10.1016/S0269-7491(98)00016-5.
Bobbink R, Hicks K, Galloway J, Spranger T, Alkemade R, Ashmore M, Bustamante M, Cinderby S, Davidson E, Dentener F, Emmett $B, 2010$. Global assessment of nitrogen deposition effects on terrestrial plant diversity: a synthesis. Ecol Appl 20(1): 30. https:// doi.org/10.1890/08-1140.1.

Cisneros Vaca C, Tol CVD, Ghimire CP, 2018. The influence of long-term changes in canopy structure on rainfall interception loss: A case study in Speulderbos, the Netherlands. Hydrol Earth Sys. Sci 22: 3701-3719. https://doi.org/10.5194/hess-22-3701-2018.

Clark CM, Cleland EE, Collins SL, Fargione JE, Gough L, Gross KL, Pennings SC, Suding KN, Grace JB, 2007. Environmental and plant community determinants of species loss following nitrogen enrichment. Ecol Lett 10(7): 596-607. https://doi.org/10.1111/i.1461-0248.2007.01053.x.

Clarke N, Žlindra D, Ulrich E, Mosello R, Derome J, Derome K, König N, Lövblad G, Draaijers GPJ, Hansen K, Thimonier A, Waldner P, 2016. Part XIV: Sampling and Analysis of Deposition. In: UNECE ICP Forests Programme Co-ordinating Centre (ed): Manual on methods and criteria for harmonized sampling, assessment, monitoring and analysis of the effects of air pollution on forests. Thünen Institute of Forest Ecosystems, Eberswalde, Germany, 32 p. https://www.icpforests.org/pdf/manual/2016/ICP Manual 201601 part14. pdf. Avaialable online: (13 September 2021).

De Marco A, Proietti C, Anav A, Ciancarella L, D'Elia I, Fares S, Fornasier MF, Fusaro L, Gualtieri M, Manes F, Marchetto A, Mircea M, Paoletti E, Piersanti A, Rogora M, Salvati L, Salvatori E, Screpanti A, Vialetto G, Vitale M, Leonardi C, 2019. Impacts of air pollution on human and ecosystem health, and implications for the National Emission Ceilings Directive: Insights from Italy. Environ Int 125: 320-333. https://doi.org/10.1016/j.envint.2019.01.064.

De Marco A, Proietti C, Cionni I, Fischer R, Screpanti A, Vitale M, 2014. Future impacts of nitrogen deposition and climate change scenarios on forest crown defoliation. Environ Pollut 194: 171-180. https://doi. org/10.1016/j.envpol.2014.07.027. 
De Vries W, Dobbertin MH, Solberg, S, van Dobben HF, Schaub M, 2014. Impacts of acid deposition, ozone exposure and weather conditions on forest ecosystems in Europe: An Overview. Plant Soil 380: 1-45. https://doi.org/10.1007/s11104-014-2056-2.

EEA, 2019. NEC Directive Reporting Status 2018. Available online: https://www.eea.europa.eu/themes/air/national-emissionceilings/nec-directive-reporting-status-2018. (18 September 2021).

Erisman JW, Galloway JN, Seitzinger S, Bleeker A, Dise NB, Petrescu AR, Allison ML, de Vries W, 2013 Consequences of human modification of the global nitrogen cycle. Phil Trans R Soc B 368: 20130116. https://doi.org/10.1098/rstb.2013.0116.

FAO and Plan Bleu, 2018. State of Mediterranean Forests 2018. Food and Agriculture Organization of the United Nations, Rome and Plan Bleu, Marseille. ISBN FAO: 978-92-5-131047-2.

Ferretti M, Marchetto A, Arisci S, Bussotti F, Calderisi M, Carnicelli S, Cecchini G, Fabbio G, Bertini G, Matteucci G, De Cinti B, 2014. On the tracks of nitrogen deposition effects on temperate torests at their Southern European range-an observational study from Italy. Glob Change Biol 20(11): 3423-3438. https://doi.org/10.1111/gcb.12552.

Gaige E, Dail DB, Hollinger DY, Davidson EA, Fernandez IJ, Sievering H, White A, Halteman W, 2007. Changes in canopy processes following whole- forest canopy nitrogen fertilization of a mature spruce-hemlock forest. Ecosystems 10: 1133-1147. hittps://doi. org/10.1007/s10021-007-9081-4.

García-Gómez H, Izquieta-Rojano S, Aguillaume L, González-Fernández I, Valiño $F$, Elustondo D, Santamaría JM, Àvila A, Bytnerowicz A, Bermejo V, Alonso R, 2018. Joining empirical and modelling approaches to estimate dry deposition of nitrogen in Mediterranean forests. Environ Pollut 243: 427-436. https://doi.org/10.1016/j. envpol.2018.09.015.

HAOP 2015. Godišnje izvješće o praćenju kvalitete zraka na području Republike Hrvatske za 2014. godinu, Zagreb, Croatia. [in Croatian].

HAZU, 2013. Šumarstvo i poljoprivreda hrvatskog Sredozemlja na pragu Europske unije. In: Anić I, Tomić F, Matić S (eds) Zbornik radova sa znanstvenog skupa Zagreb, Hrvatska akademija znanosti i umjetnosti, Znanstveno vijeće za poljoprivredu i šumarstvo, Znanstveno vijeće za zaštitu prirode, Zagreb, Croatia, 327 p. [in Croatian]

ISO 10304, 1998. Water Quality - Determination of $\mathrm{F}^{-}, \mathrm{Cl}^{-}, \mathrm{Br}^{-}, \mathrm{NO}_{3}{ }^{-}, \mathrm{NO}_{2}$ , $\mathrm{PO}_{4}^{3-}, \mathrm{SO}_{4}^{2}$ Using Liquid Chromatography of Ions.

ISO 14911, 1998 Water Quality - Determination of Dissolved $\mathrm{Na}^{+}, \mathrm{NH}_{4}{ }^{+}$, $\mathrm{K}^{+}, \mathrm{Mn}^{2+}, \mathrm{Ca}^{2+}, \mathrm{Mg}^{2+}$ Using lon Chromatography.

Izquieta-Rojano S, García-Gomez H, Aguillaume L, Santamaría JM, Tang YS, Santamaría C, Valiño F, Lasheras E, Alonso R, Àvila A, Cape JN, Elustondo D, 2016. Throughfall and bulk deposition of dissolved organic nitrogen to holm oak forests in the Iberian Peninsula: Flux estimation and identification of potential sources. Environ Pollut 210: 104-112. https://doi.org/10.1016/i.envpol.2015.12.002.

Jakovljević T, Lovreškov L, Jelić G, Anav A, Popa I, Fornasier MF, Proietti C, Limić I, Butorac L,Vitale M, De Marco A, 2021. Impact of ground-level ozone on Mediterranean forest ecosystems health. Sci Total Environ 783: 147063. https://doi.org/10.1016/i.scitotenv.2021.147063.

Jakovljević T, Marchetto A, Berković K, Rosa J, Potočki A, 2013. Atmospheric eposition measurement in the lowland forest ecosystem of Pokupsko basin in Croatia. Period Biol 115: 363-370. https://hrcak.srce.hr/110831.

Jakovljević T, Marchetto A, Lovreškov L, Potočić N, Seletković I, Indir K, Jelić G, Butorac L, Zgrablić Ž, De Marco A, Simioni G, Ognjenović M, Tušek AJ, 2019. Assessment of atmospheric deposition and vitality indicators in Mediterranean forest ecosystems. Sustainability 11(23): 6805. https://doi.org/10.3390/su11236805.

König N, Kowalska A, Brunialti G, Ferretti M, Clarke N, Cools N, Derome J, Derome K, de Vos B, Fuerst A, Jakovljević T, Marchetto A, Rosario M, O'Dea P, Tartari G, Ulrich E, 2016. Part XVI: Quality assurance and control in laboratories. In manual on methods and criteria for harmonized sampling, assessment, monitoring and analysis of the effects of air pollution on forests; UNECE ICP Forests Programme Co-ordinating Centre, Ed.; Thünen Institute of Forest Ecosystems: Eberswalde, Germany, $46 \mathrm{p}$.
Köpen W, Volken E, Brönnimann S, 2011. The thermal zones of the Earth according to the duration of hot, moderate and cold periods and to the impact of heat on the organic world. Meteorol Z 20(3): 351-360. https://doi.org/10.1127/0941-2948/2011/105.

Lu X, Mo J, Dong S, 2008. Effects of Nitrogen Deposition on Forest Biodiversity. Acta Ecol Sin 28: 5532-5548. https://doi.org/10.1016/ S1872-2032(09)60012-3.

Matić S, Prpić B, Jakovac H, Vukelić J, Anić I, Delač D, Matić S, 2011. Preface. In: Matić $S$ (ed). Forest of the Croatian Mediterranean. Akademija Šumarskih Znanosti, Zagreb, Croatia, pp. 5-7.

Meixner T, Fenn M, 2004. Biogeochemical budgets in a Mediterranean catchment with high rates of atmospheric $\mathrm{N}$ deposition - importance of scale and temporal asynchrony. Biogeochemistry 70(3): 331-356. https://doi.org/10.1007/s10533-003-4106-3.

Mużyło A, Llorens P, Domingo $F, 2012$. Rainfall partitioning in a deciduous forest plot in leafed and leafless periods. Ecohydrology 5(6): 759-767. https://doi.org/10.1002/eco.266.

Myers N, Mittermeier RA, Mittermeier CG, da Fonseca GAB, Kent J, 2000. Biodiversity hotspots for conservation priorities. Nature 403 : 853-858. https://doi.org/10.1038/35002501.

Ochoa-Hueso R, Allen EB, Branquinho C, Cruz C, Dias T, Fenn ME, Esther Pérez-Corona M, Sheppard LJ, Stock WD, 2011. Nitrogen deposition effects on Mediterranean-type ecosystems: An Ecological Assessment. Environ Pollut 159(10): 2265-2279. https://doi. org/10.1016/i.envpol.2010.12.019.

Perez L, Tobias A, Querol X, Alastuey A, Viana M, Pey J, González-Cabré M, Valero N, Künzli N, Sunyer J, 2008 Coarse particles from Saharan dust and daily mortality. Epidemiology 19(6): 800-807. https://doi. org/10.1097/EDE.0b013e31818131cf.

Pey J, Pérez N, Castillo S, Viana M, Moreno T, Pandolfi M, LópezSebastián JM, Alastuey A, Querol X, 2009. Geochemistry of regional background aerosols in the Western Mediterranean. Atmos Res 94(3): 422-435. https://doi.org/10.1016/i.atmosres.2009.07.001.

Shibata H, Branquinho C, McDowell WH, Mitchell MJ, Monteith DT, Tang J, Arvola L, Cruz C, Cusack DF, Halada L, Kopacek J, Maguas C, Sajidu S, Schubert H, Tokuchi N, Zahora J, 2015. Consequence of altered nitrogen cycles in the coupled human and ecological system under changing climate: the need for long-term and site-based research. Ambio 44(3): 178-193. https://doi.org/10.1007/s13280-014-0545-4.

Sievering H, Tomaszewski T, Torizzo J, 2007. Canopy uptake of atmospheric $\mathrm{N}$ deposition at a conifer forest: part I-canopy $\mathrm{N}$ budget, photosynthetic efficiency and net ecosystem exchange. Tellus $B$ 59(3): 483-492. https://doi.org/10.1111/j.1600-0889.2007.00264.x.

Skevin-Sovic J, Djuricic V, Kosanovic C, 2012. Major ions wet deposition and trends during the last decade on the eastern Adriatic coast. WIT Trans Ecol Envir 157: 339-349. https://doi.org/10.2495/AIR120301.

Topić V, Butorac L, 2011. Antierosion, hydrological and waterprotection role of Mediterranean forests. In: Matić S (ed) Forest of the Croatian Mediterranean. Akademija šumarskih znanosti i Hrvatske šume, Zagreb, Croatia, pp. 307-325.

Topić, V, Butorac L, Durmešić A, Gelić J, 2020. Soil erosion interrential drainage basen of rivers Jadro and Žrnovnica after forest fires. In: Anić I (ed) Forest management in the contexst of climate changes and natural disaster. Croatian Academy of Sciences and Arts, Zagreb, Croatia, pp. 103-134.

Zabret K, Rakovec J, Šraj M, 2018. Influence of meteorological variables on rainfall partitioning for deciduous and coniferous tree species in urban area. J Hydrol 558: 29-41. https://doi.org/10.1016/j. ihydrol.2018.01.025.

Zabret K, Šraj M, 2018. Spatial variability of throughfall under single birch and pine tree canopies. Acta hydrotechnica 31(54): 1-20. https://doi.org/10.15292/acta.hydro.2018.04. 